Uludag Univ. J. Fac. Vet. Med.

36 (2017), 1,2: 25-28

\title{
Erkek Bir Köpekte Meme Bezinde Anaplastik Karsinoma Olgusu
}

\author{
Geliş Tarihi:22.06.2017 \\ Düzeltme Tarihi:15.12.2017, Kabul Tarihi:25.12.2017 \\ Vildan ASLAN ${ }^{1}$, Hilal ÇEŞME ${ }^{1}$, Ayşe Meriç MUTLU², \\ İ.Taci CANGÜL ${ }^{2}$, Hakan SALCI ${ }^{1}$
}

\begin{abstract}
Özet: Dokuz yaşlı, erkek, Rottweiler ırkı bir köpek, sağ ikinci torakal meme lobunda büyüme şikayetiyle kliniklerimize getirildi. Klinik olarak sağ torakal 2. papilla mamma yaklaşık $5 \times 4 \times 3 \mathrm{~cm}$ boyutlarında, ostium papillare ise ülseratif ve enfekteydi. Toraksın radyografisinde metastazı ortaya koyacak herhangi bir bulguya rastlanmadı. Ultrasonografik muayenede meme dokusu heterojen bir görünüme sahipti ve hiperekoik bir alan ile çevriliydi. Genel anestezi altında ilgili meme lobunun mastektomisi gerçekleştirildi. Histopatolojik incelemede meme bezi epitel hücrelerinin yer yer solid ve papiller tarzda ürediği ve hücrelerde mitotik aktivitenin oldukça yüksek olduğu gözlendi. Bu bulgulara dayanarak kitleye anaplastik karsinoma tanısı konuldu. Erkek köpeklerde nadir olarak gözlenen anaplastik meme bezi karsinoması bu olgu sunumu ile rapor edilmektedir.
\end{abstract}

Anahtar Kelimeler: Erkek köpek, meme bezi, anaplastik karsinoma.

\section{Anaplastic Carcinoma of the Mammary Gland in a Male Dog}

\begin{abstract}
A 9 year-old, male, Rottweiler was presented to our clinic with the complaint of abnormal growth in the second, right thoracal mammary lobe. Clinically, the second thoracic papilla mamma was about $5 \times 4 \times 3 \mathrm{~cm}$ in size, and ostium papillare was ulcerative and infected. Radiography of the thorax revealed no findings indicative of metastasis. Ultrasonographical examination revealed that mammary tissue had heterogeneous appearance and was surrounded by hyperechoic areas. The mastectomy of the mammary lobe was performed under general anesthesia. Histopathological examination revealed solid and papillary proliferations of glandular epithelia and a high mitotic activity. A diagnosis of anaplastic mammary carcinoma was made based on these findings. Anaplastic mammary gland carcinomas are rarely encountered in male dogs and one incident is reported in this case presen-tation.
\end{abstract}

Keywords: Male dog, mammary gland, anaplastic carcinoma.

\section{Giriş}

Köpeklerde meme tümörleri, deri tümörlerinden sonra en s1k rastlanan tümörlerdir. Köpeklerde rastlanan tümörlerin yaklaşık \%2530’u meme tümörüdür ve bunların \%50-65'inin miks tümör, \%25-40'ının karsinoma, geriye kalanların da hiperplazi, adenoma ve miyoepitelyoma olduğu bildirilmektedir ${ }^{1,2,10}$.
Meme tümörleri dişi köpeklerde sıklıkla teşhis edilmekte ${ }^{1,6,10}$, erkek köpeklerde ise daha nadir olarak gözlenmektedir ${ }^{1,3,8,12}$. Köpeklerde meme tümörlerine daha çok 8-12 yaş aralığında (ortalama 5 yaşından büyüklerde) rastlanmaktad $1 r^{1,3}$. Meme bezini etkileyen ve histolojik inceleme ile teşhis edilen en yaygın neoplazi tipi epitelyal tümörlerdir ${ }^{1,6,10}$.

Anaplastik karsinomalar en malign karaktere sahip olan epitel kökenli tümörlerdir. Ade-

1 Uludağ Üniversitesi, Veteriner Fakültesi, Cerrahi Anabilim Dalı, 16059, Bursa.

2 Uludağ Üniversitesi, Veteriner Fakültesi, Patoloji Anabilim Dalı, 16059, Bursa. hsalci@uludag.edu.tr 
nokarsinoma, solid karsinoma, skuamoz hücreli karsinoma ya da musinoz karsinoma gibi tümörlerden farklı olarak, tümörün hangi hücreden köken aldığı tam olarak belirlenemez ${ }^{1,6,9}$. Anaplastik karsinomalar köpeklerde diffuz ve invaziv karakterde olup, özellikle bölgesel lenf nodüllerine ve akciğerlere metastaz yapma eğiliminde$\operatorname{dir}^{1,4-6,9,10}$.

Sunulan olguda erkek bir köpekte meme bezinde nadir olarak rastlanan anaplastik karsinomanın veteriner literatüre kazandırılması amaçlanmıştır.

\section{Olgunun Tanımı}

Dokuz yaşl1, erkek, Rottweiler 1rkı bir köpek son üç ay içerisinde sağ torakal 2. meme lobunun giderek büyümesi ve meme başından zaman zaman kanla karışık irinli akıntı gelmesi şikayetiyle Uludağ Üniversitesi, Veteriner Fakültesi, Cerrahi Anabilim Dalı Kliniklerine getirildi.

Yapılan muayenede, hayvanın submandibular ve popliteal lenf yumrularının hafif büyüdüğü, sağ torakal 2. papilla mammanın yaklaşık $5 \times 4 \times 3 \mathrm{~cm}$ boyutlarında olduğu, ostium papillarenin ülseratif, kanla karışık irinli bir akıntıyla bulaşık olduğu saptandı (Şekil 1). Palpasyonda, papilla mammanın yumuşak, çevresinin ise katı esnek kıvamda olduğu, deri altı bağ dokuyla ilişkisi olmayan sıcak, ağrılı bir şişkinliğin varlığı saptandı. Hematolojik değerlerin normal sinırlar içerisinde olduğu görüldü.

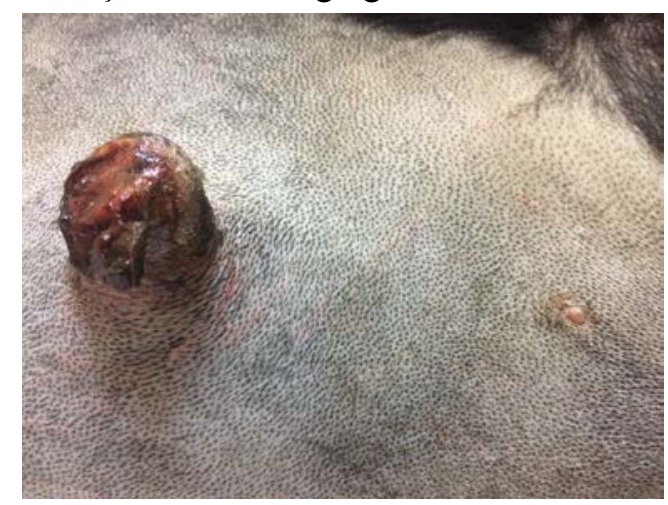

Şekil 1. Olgunun preoperatif klinik görünümü.

Figure 1. Preoperative clinical aspect of the case.

Radyolojik olarak toraksın lateral radyografisinde intratorakal organlara ilişkin metastaz varlığına rastlanmadi. Ultrasonografik muayenede meme lobunun heterojen bir görünüm sergilediği ve hiperekoik bir alan ile çevrili olduğu gözlendi (Şekil 2). Bu bulgular temelinde meme bezinden köken alan bir tümörden şüphelenildi ve cerrahi olarak ilgili meme bezinin çıkarılmasına karar verildi.

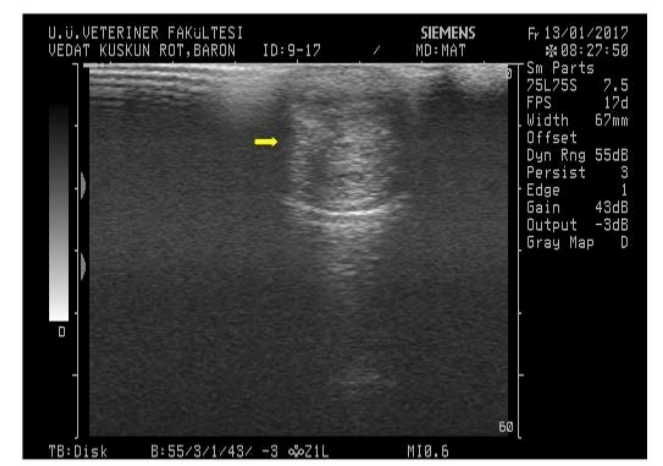

Şekil 2. Meme bezi dokusunun heterojenik ultrasonografik görünümü (ok).

Figure 2. Heterogenic ultrasonographic view (arrow) of the mammary gland tissue.

Preoperatif antibiyoterapi amaçlı sefurok$\operatorname{sim} 20 \mathrm{mg} / \mathrm{kg}$ po. (Cefaks ${ }^{\circledR}$, Deva İlaç, İstanbul) kullanıldı. Sedasyon amaciyla $1,5 \mathrm{mg} / \mathrm{kg}$ dozda xylazine $\mathrm{HCl}$ (Alfazyne ${ }^{\circledR}$, Egevet, İzmir) ve indüksiyon için ketamin $\mathrm{HCl}$ (Alfamine ${ }^{\circledR}$, Egevet) $6 \mathrm{mg} / \mathrm{kg}$ dozda $\mathrm{im}$. uygulandi. Anestezi idamesi \%2'lik isofluran (Forane ${ }^{\circledR}$, Abbott, İngiltere) ile sağlandı. Preoperatif hazırlık sonrası meme bezi dokusu ensizyon ve diseksiyon işlemleri ile eksize edilerek vücuttan uzaklaştırıl$\mathrm{d}_{1}$ (Şekil 3). Dokular tekniğine uygun bir şekilde rutin olarak kapatıldı. Alınan doku formaldehit solüsyonuna konularak histopatolojik inceleme amacıyla Patoloji Anabilim Dalı laboratuvarına gönderildi. Burada rutin doku takibi işlemlerinden sonra $5 \mu \mathrm{m}$ kalınlığında kesitler alındı ve hematoksilen-eozin boyama ile boyand.

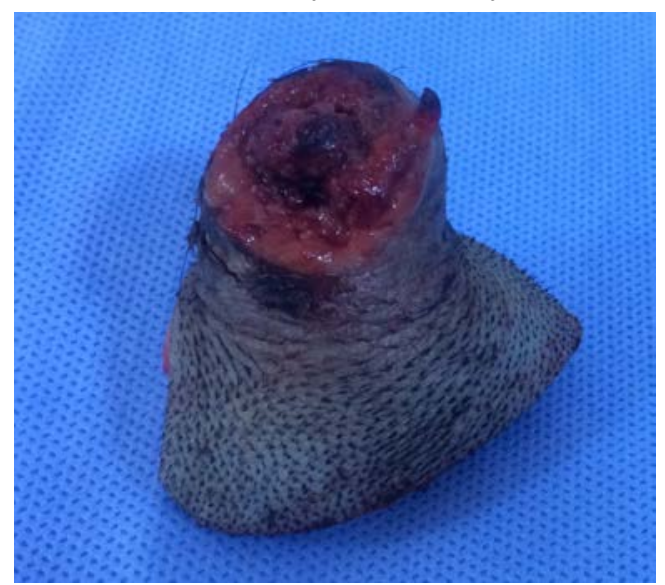

Şekil 3. Cerrahi olarak çıkartılan papilla mammanin görünümü.

Figure 3. The view of the surgically removed papilla mamma. 
Histopatolojik incelemede, kitlenin yer yer solid kümeler şeklinde dağılım gösteren, yer yer ise lümen benzeri yapılar oluşturma eğiliminde olan düzensiz dağılımdaki hücrelerden oluştuğu gözlendi. Hücrelerin genel olarak ökromatik yapıda, oval-yuvarlak şekilli çekirdeklerinin olduğu, çekirdekçiklerin genellikle belirgin olmadığı, ancak bazı hücrelerde 1-2 çekirdekçik bulunduğu, kromatinin ise genellikle dağınık bir yapıda olduğu görüldü. Hücre sınırları genellikle belirgin değildi. Hücre çekirdekleri arasında şekil ve büyüklük açısından belirgin farklar olduğu, yer yer çok büyük hücre çekirdeklerinin bulunduğu dikkati çekti. Bazı hücrelerin sitoplazmaları içerisinde belirgin vakuolleşmelerin ş̧ekillendiği görüldü. Hücrelerde mitotik aktivitenin oldukça yüksek olduğu (x400'lük alan büyütmesinde 1-2 mitoz) gözlendi. Bazı bölgelerde hücreler arasında geniş fibröz alanlar ile birlikte yer yer küçük kanama sahalarına rastlandı. Hücrelerin boyut ve şekillerindeki farklılıklar, yüksek mitoz oranı ve düzensiz yapıdan dolayı kitleye anaplastik karsinoma teşhisi konuldu (Şekil 4).

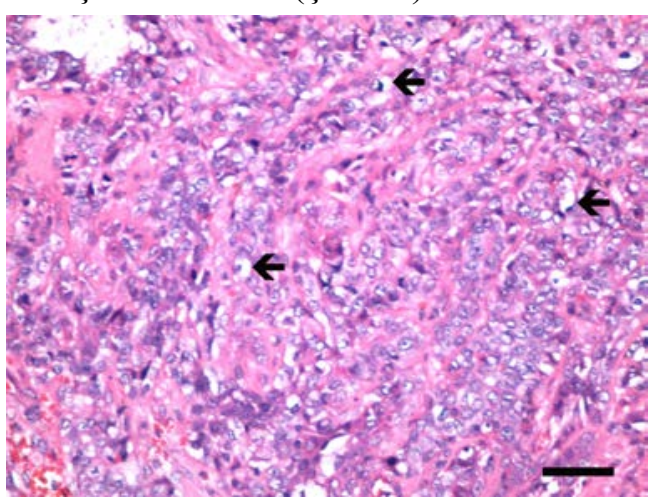

Şekil 4. Az miktarda bağdoku ile birbirinden ayrlmış solid hücre kümeleri, hücre çekirdeklerinin ökromatik yapısı ve bazı hücrelerin sitoplazmalarındaki vakuolleşmeler (ok). (Hematoksilen-eozin boyama, çubuk: $100 \mu \mathrm{m})$.

Figure 4. Solid cell clusters separated with minimal connective tissue, euchromatic cell nuclei and cytoplasmic vacuolisations in some cells (arrow). (Hematoxylin-eosin staining, bar: $100 \mu \mathrm{m})$

Postoperatif dönemde 5 gün boyunca sefuroksim $20 \mathrm{mg} / \mathrm{kg}$, po. (Cefaks ${ }^{\circledR}$, Deva, İstanbul) ve 3 gün boyunca carprofen $50 \mathrm{mg}, 1 \times 2 \mathrm{tbt}$, po. (Rimadyl ${ }^{\circledR}$, Pfizer, İstanbul) uygulamaları yapıld1. Postoperatif 10. günde yapılan kontrolde derinin kapandığı ve yara hattının iyileştiği gözlendi.

\section{Tartışma}

Meme bezi tümörleri dişi köpeklerde \%42, erkek köpeklerde ise \%2,7 görülme oranlarına sahiptir. Erkek köpeklerde meme tümörlerinin daha çok orta yaşlarda görüldüğü bildirilmiştir ${ }^{1,8,10}$. Sunulan olgumuzda meme tümörüne 9 yaşl1, erkek bir köpekte rastlanmıştır.

Tümör olgularında prognoz ve uygulanacak olan tedavi planı açısından tümörün tipinin belirlenmesi gerekir. Meme tümörlerinde tümörün tipini belirlemek amaciyla sadece sitolojik muayene yeterli bilgi sağlamamakta, histolojik ve immunohistokimyasal incelemeler gerekli olmaktadır. Yardımcı bir tanı yöntemi olarak ultrasonografik muayene ile tümörün boyutu, şekli, içsel yapıları, çevre dokulara invazyonu ve vaskülarizasyonu hakkında değerli bilgiler elde etmek mümkündür ${ }^{10,11}$. Olgumuzda ultrasonografik bulgular meme bezi lobunun hiperekoik bir alan ile çevrili heterojen bir yapıda olduğunu göstermiş ve bu görünüm bizi tümöral oluşum yönüyle şüphelendirmiştir.

Anaplastik karsinoma, interlobuler konnektif dokuya ve lenf damarlarına invaze olan malign meme tümörlerinden biridir $^{1,4,5,7,10}$. Anaplastik karsinomalar kesinlikle invaziv olup meme bezi tümörlerinin metastaz ve boyut özelliklerine dayanarak yapılan derecelendirmede ikinci dereceli tümör olarak belirlenmiştir ${ }^{1,10}$. Tümör tedavisinde tümörün özelliklerine göre cerrahi eksizyon, radyoterapi ve/veya antikanser/sitotoksik kemoterapi kullanılmakta, ancak olgumuzda görüldüğü karakterdeki tümörlerde genellikle cerrahi eksizyon önerilmektedir. Anaplastik karsinomanın çevre dokulara ve lenfatik sisteme metastazı hızlı olduğu için çoğu zaman cerrahi sağaltım tek başına yeterli olmamaktadır ${ }^{1,9,10}$. Sunulan olguda meme dokusundaki tümör cerrahi eksizyon ile vücuttan uzaklaştırılmıştır.

Histopatojik incelemede, papillar ya da solid tarzda çoğalmaların bulunması, pleomorfik hücreler ve hücre çekirdeğinin ökromatik olması, mitotik aktivitenin yüksek olması, çok sayıda yangı hücresi infiltrasyonlarına rastlanmas1 olgumuzun daha önceki raporlarla örtüşen bulgulara sahip olduğunu göstermiştir ${ }^{4,5,9,10}$. Bu bulgular temelinde erkek bir köpekte meme bezinde rastladığımız tümöral kitlenin anaplastik karsinoma olduğu görülmüştür. 


\section{Kaynaklar}

1. Argyle, D. J., Brearley, M. J., Turek, M. M. 2008. Decision Making in Small Animal Oncology, Wiley-Blackwell, USA.

2. Atalay Vural, S., Aydın, Y. 2001. Ankara'da 1973-1998 yılları arasında incelenen köpek meme tümörleri. Turk J Vet Anim Sci, 25: 233-239.

3. Dileepkumar, K. M., Maiti, S. K., Kumar, N., Zama, M.M. S. 2014. Occurrence of canine mammary tumours. Indian J Canine Pract, 6: 179-183.

4. Goldschmidt, M. H. 2010. Review of the prognostic evaluation of canine mammary carcinomas. Proceeding of the ACVP/ASVCP Concurrent Annual Meetings, 30 October-3 November. Baltimore, Maryland, USA.

5. Hahn, K. A. 2002. Veterinary Oncology, Butterworth-Heinemann, USA.

6. Kim, J. H., Kim, W. J., Park, J., Shin, J. I., Yoon, H. Y. 2005. Canine mammary anaplastic carcinoma with concurrent aorto-iliac thrombosis in a dog: a case report. Vet Med (Praha), 60: 391-398.
7. Kudnig, S. T., Seguin, B. 2012. Veterinary Surgical Oncology, Wiley-Blackwell, USA.

8. Maiti, S. K., Kumar, D. K. M., Kumar, S., Ravindran, N. A., Mathew, D., Palakkara, S., Muthalavi, M. A., Kumar, N. 2014. Mammary gland tumours in male dogs: a hormonal and tumour marker study. Vet Arh, 84: 537-548.

9. Misdorp, W., Cotchin, E., Hampe, J. F., Jabara, A. G., Sandersleben, J. V. 1973. Canine malignant mammary tumors. Vet Pathol, 10: 241-256.

10. Morris, J., Dobson, J. 2001. Small Animal Oncology, Wiley-Blackwell, USA.

11. Nyman, H. T., Nielsen, O. L., McEvoy, F. J., Lee, M. H., Martinussen, T., Hellmen E., Kristensen, A. T. 2006. Comparison of B-mode and Doppler ultrasonographic findings with histologic features of benign and malignant mammary tumors in dogs. Am J Vet Res, 67: 985-991.

12. Sorenmo, K. U., Shofer, F. S., Goldschmidt, M. H. 2000. Effect of spaying and timing of spaying on survival of dogs with mammary carcinoma. $J$ Vet Intern Med, 14: 266-270. 